\title{
Ecological stability of alpine treeline ecotone formed by beech (Fagus sylvatica L.) in Ďumbier Low Tatras
}

\section{J. Mičovský}

Forests of the Slovak Republic, state enterprise, Forest District Brusno, Oremlaz 410, 97662 Brusno, External PhD student at the Department of Silviculture, Technical University in Zvolen, e-mail:jan.micovsky@gmail.com

\begin{abstract}
Mičovský, J. 2014: Ecological stability of alpine treeline ecotone formed by beech ( $F a-$ gus sylvatica L.) in Ďumbier Low Tatras. Beskydy, 7 (2): 87-98

The paper analyses the results of the ecological stability research of beech (Fagus sylvatica L.) stands at the alpine tree-line ecotone in the Dumbier part of Law Tatras. The applied methodology by Vološčuk (2000) is based on the approximation of the currenttreespecies composition withrespect to the originalones, crownratio, slenderness quotient, sanitary coefficient and vertical species profile of the stands. The resulting value of ecological stability of the stands, typologically classified into a group of forest types Fageto-Aceretum humile, was increased by approximation of $80.0-82.5 \%$, slenderness quotient $0.55-0.60 \mathrm{~m} \cdot \mathrm{cm}^{-1}$ and sanitary coefficient. Vitality was assessed with regard to the most common damage to individual, more than 160-year-old beech trees at the alpine treeline ecotone in the form of necrosis. Vertical and horizontal structure of the stands was influenced mainly by dense tree clusters. The value of ecological stability was decreased by average crown ratio of individual trees ranging from 0.47-0.57. Based on the final index of ecological stability ES 16-24, beech forests in the alpine treeline ecotone may be considered as very stable.
\end{abstract}

Keywords: European beech (Fagus sylvatica L.), alpine treeline ecotone, ecological stability

\section{Introduction}

The southern part of the Dumbier Law Tatras in the $6^{\text {th }}$ vegetation zone was originally formed by beech (Fagus sylvatica L.), which was in the $7^{\text {th }}$ vegetation zone naturally followed by spruce forests (Eu-Vaccinio-Piceenion p.p) (Bystrický 2007). The changes in structure and tree species composition began to occur first in the lower parts of the mountains in the $13^{\text {th }}$ and $14^{\text {th }}$ century during the great German colonization, and then later in the third period of the settlement during the Wallachian colonization also in the high altitude forests (Midriak 1973). Wallachians cut down forests and burned them down to enlarge pastures. Particularly the southern exposures were completely deforested (Holtmeier 2009). This created the upper treeline formed by beech. Since beech does not naturally reach the alpine tundra ecotone in our region (Plesník 1971), it represents the declined altitudinal treeline, with functions of alpine forests in $7^{\text {th }}$ vegetation zone in the areas where forest has been previously destroyed by grazing (Gubka 1999).

Plesník's (1971) definition of the alpine treeline, who defines it as a line connecting the highest points of a continuous forest, is the most often used definition in our field. The strict line of the previous definition is often modified by a term ecotone, which indicates a transition zone between two communities forest and alpine tundra (Holtmeier 2009).

Fekete, Blattny (1914) report the upper treeline of beech in the Slovak Carpathians at an altitude of $1485 \mathrm{~m}$ a.s.l. According to Kukla (2011) the vitality of beech in macroclimatic conditions of $6^{\text {th }}$ vegetation zone is already greatly reduced. It maintains the dominant position to fir particularly in mesotrophic and eutrophic natural geobiocenosis, or in geobiocenoses influenced by alpine 
phenomenon where fir and spruce is damaged by abiotic (wet snow, wind, frost) and consequently biotic factors. Beech enters alpine spruce stands in a shrub form especially in the area south of the main climate partition line of Slovakia, for example the western part of the Low Tatras (Kukla 2011).

Beech forests at the treeline ecotone with an admixture of rowan, sycamore, fir and spruce has a limited vertical growth conditioned by a long-term exposure to intense air flow in the ridge lines of upper areas at an altitude above $1000 \mathrm{~m}$ a.s.l. They represent mostly sparse, low-quality vegetation (Pagan 1999). Due to inaccessibility and assortment structure were the stands below the upper treeline for the decades left untouched, and despite the Wallachian colonization in the $15^{\text {th }}$ and $16^{\text {th }}$ centuries, current ecotone consists of a high proportion of native forests (Zdycha et al. 1992).

As the main object of interest in solving problems of alpine forests in Slovakia are spruce forests of supramontane and subalpine level (Kucbel 2011), papers analyzing primeval forests with the dominance of beech located in the $6^{\text {th }}$ forest vegetation zone reaching the upper treeline are absent in the available literature (Saniga et al. 2013).

The aim of this article is to analyze the ecological stability of the alpine treeline ecotone that consists of beech (Fagus sylvatica L.), as well as verify the hypothesis that near-natural beech stands at the alpine treeline ecotone maintain sufficient ecological stability even when facing various intensity of human intervention.

\section{Materials and Methodology}

Permanent research plots were established at the alpine treeline ecotone in the southern exposure of the Dumbier Law Tatras. From the climatic point of view is the researched area situated between cool to cold mountain areas with an average July temperature $\leq 12^{\circ} \mathrm{C}$ (Lapin et al. 2002). The average annual air temperature is $2-4{ }^{\circ} \mathrm{C}$ (Štastný et al. 2002), the average annual temperature of the active surface of soil is $4-5^{\circ} \mathrm{C}$ (Tomlain, Hrvol' 2002), average annual rainfall is 1600 to $2000 \mathrm{~mm}$ (Faško, Štastný 2002). Geological underlay consists of muscovite-biotite granodiorites to granites (Biely et al. 1992).

Empirical material comes from compartments 2252A (48 $\left.53^{\prime} 14.99^{\prime \prime} \mathrm{S}, 19^{\circ} 20^{\prime} 56.50^{\prime \prime} \mathrm{V}\right)$ and $2128 \quad\left(48^{\circ} 52^{\prime} 23.86^{\prime \prime} \mathrm{S}, 1^{\circ} 23^{\prime} 14.30^{\prime \prime} \mathrm{V}\right)$, belonging to forest management unit Slovenská Lupča, forest unit Brusno - state. In the compartment 2252A was established a transect $\mathrm{T}_{\mathrm{I}}$ with a dimension of $50 \times 100 \mathrm{~m}$ having a longer side running along the fall line, which was divided into four permanent research plots $\mathrm{TVP}_{\mathrm{A}}-\mathrm{TVP}_{\mathrm{D}}$ measuring $25 \times 50 \mathrm{~m}$. In the compartment 2128 was established an identical transect $\mathrm{T}_{\mathrm{II}}$ with $\mathrm{TVP}_{\mathrm{E}}-\mathrm{TVP}_{\mathrm{H}}$. Individual $\mathrm{TVP}_{\mathrm{A}-\mathrm{H}}$ in transects $\mathrm{T}_{\mathrm{I}}$ and $\mathrm{T}_{\mathrm{II}}$ define altitude zones with an interval of approximately 10 vertical meters from the altitude of 1340$1380 \mathrm{~m}$ a.s.l. All individual trees with diameter $d_{1,3} \geq 5 \mathrm{~cm}$ were noted into the system of vectors $\mathrm{X}, \mathrm{Y}$ in the transects.

The area of the compartment 2252A is 17.23 hectares, southern exposure, slope $45 \%$, age 160 years, stand density 0.8 , species structure beech 90 , spruce 10, growing stock $257 \mathrm{~m}^{3} \cdot \mathrm{ha}^{-1}$, basal area $35.12 \mathrm{~m}^{2}$. ha-1, average stand diameter $25.42 \mathrm{~cm}$.

The area of the compartment 2128 is 8.62 hectares, southern exposure, slope $45 \%$, age 160 years, stand density 0.9 , species structure beech 93, maple 2.5, spruce 2.5 , larch 2 , growing stock $295 \mathrm{~m}^{3}$. ha-1, basal area $37.88 \mathrm{~m}^{2}$.ha-1, average stand diameter $38.71 \mathrm{~cm}$. When identifying primeval forests residuals in Slovakia (Jasík, Polák 2011), the stand was included in the native stands with a primeval forest character.

The compartments are typologically classified according to Hančinský (1972) into alpine beech forests, a group of forest types Fageto-Aceretum humile (Fac hum v), forest type 6411 - Stunted sycamore - beech woods. In the system Natura 2000 these are identified as maple-beech mountain forests (9140 - NATURA code, LS 5.3 - code SK).

Ecological stability (ES) of the stands was evaluated using methodology by Vološčuk (2000), which consists of approximation of the current tree species composition in regard to native species dominance (a), crown ratio (cr), slenderness quotient (sq), sanitary coefficient (sc) and a deviation of a current vertical structure from a model of the three-layer structure (cl). ES index is calculated by the formula (Vološčuk 2000): $E S=5 a+3 s c+c r+s q+c l$

According to the resulting index ES, the stands were included in the scale (Vološčuk 2000): high ecological stability - resulting index 11-15, very good ecological stability (ES 16-24), medium ecological stability (ES 25-35), small ecological stability (ES 36-46), ecosystem labile (ES 47-55). 
1) The percentage of approximation (a) represents a deviation of the current tree species structure from the original (potential) structure. It is calculated by the formula (Papánek 1967):

$$
a=100 \cdot\left(1-\frac{S O}{200}\right)
$$

SO - the degree of deviation of the current structure of each tree species from the original outlook representation according to the methodology by Vološčuk (2000).

According to the calculated percentage of approximation the stands were classified into the following scale of stability (Vološčuk 2000):
1. highly stable
2. very stable
3. moderately stable
4. less stable
5. labile

above $91 \%$ $71-90 \%$ $51-70 \%$ $31-50 \%$ up to $30 \%$

2) The level of static stability is expressed by crown ratio (cr) - the ratio of crown length $(\mathrm{m})$ to tree height $(\mathrm{m})$, and slenderness quotient (sq) - the ratio of the height (m) and a diameter in the height of $1.3 \mathrm{~m}$ above ground $d_{1,3}$ (Šmelko 2000).

Based on the value of the slenderness quotient, the static stability of trees was estimated according to the classification scheme (Míchal 1992):

$\mathrm{sq}>1.0$

sq $0.80-1.0$

sq $0.55-0.8$

sq $<0.55$ solitaires with the highest stability

By the values of crown ratio (cr) and slenderness quotient (sq) the stands were classified in a scale of stability (Vološčuk 2000):

\begin{tabular}{lrr} 
& \multicolumn{1}{c}{ cr: } & \multicolumn{1}{c}{ sq: } \\
1. highly stable & over 0.81 & less than 0.50 \\
2. very stable & $0.71-0.80$ & $0.51-0.65$ \\
3. moderately stable & $0.51-0.70$ & $0.66-0.80$ \\
4. less stable & $0.41-0.50$ & $0.81-0.95$ \\
5. labile & less than 0.40 & over 0.96
\end{tabular}

3) Sanitary coefficient (sc) was calculated as a proportion of necrotically damaged individual trees to the total number of trees in the area. As damaged were considered the trees with a degree of disease 3 and 4 according to the classification scale (Cicák, Mihál 2000):
Grade 0: no necrotic wounds on the bark,

Grade 1: small necrotic wounds (slits, cracks) occurring singly or in isolated clusters, visible only in closer inspection of the trunk,

Grade 2: small necrotic wounds (such as in grade 1) and at the same time the occurrence of larger necrotic wounds (larger cracks, fissured bark), visible by a casual inspection of the trunk,

Grade 3: larger necrotic wounds exposing the wood and partly distorting the trunk, bursting and deciduous bark, already visible from a greater distance,

Grade 4: large necrotic wounds strongly distorting the trunk or forming "break necrosis", bursting and deciduous bark, visible from the distance.

By the value of sanitary coefficient the stands were classified in a scale of ecological stability (Vološčuk 2000):
1. highly stable
2. very stable
3. moderately stable
4. less stable
5. labile

to $20 \%$ damage $21-30 \%$ $31-40 \%$ $41-50 \%$ more than $51 \%$

4. To determine the deviation of the current vertical structure from the model of the threelayer structure (vs), the growth area of the stands was divided on the basis of a upper height $\mathrm{h}_{10 \%}$ into three regular layers (Korpel' 1991). The upper height corresponds the average diameter of the top $10 \%$ of the thickest living tree individuals in transect $\left(\mathrm{h}_{10 \%}=\mathrm{f}\right.$ $\left(\mathrm{d}_{10 \%}\right)$. The upper level includes the trees with a height greater than $2 / 3$ of the upper height, the middle level includes the trees between $1 / 3$ and $2 / 3$ of the upper height and the low level includes the trees with the height less than $1 / 3$ of the upper height. The layer should only be noted when its representation is at least $10 \%$ of the total tree number.

Vertical position of trees is estimated by the classification scale by Assmann (1961 in Saniga 2009):

1) Dominant - trees with extremely firmly developed crowns.

2) Level - trees with relatively well developed (proportionally large and regular) crowns, which constitute the main stand.

3) Partially level - crowns that are still relatively normal, but compared to previous classes they are less developed. These form the lower interface of the main stand. 
4) Subdominant shaded - with a more or less shortened crown that is unilaterally developed and is cramped from two or more sides.

5) Supressed (with a compromised lifespan) - a living crown, which is capable of living only with shade-tolerant species, trees with a dying crown or completely dead trees.

A scale of ecological stability, according to the coefficient of layering (cl), represents a deviation of layering of the current stand from the model of the three-layer stand (Vološčuk 2000):

\section{Results}

\section{The approximation $(a)$ of the current tree species composition with respect to the original ones.}

For the forest type 6411 Stunted sycamore beech woods (HSLT 618 European subalpine beech woods, SLT - Fageto Aceretum humile) there is the following original representation of tree species: Beech 80, Maple 15, Rowan 5.

In transect $\mathrm{T}_{\mathrm{I}}$ compartment $2252 \mathrm{~A}$ there is the following current tree species representation rounded: Beech 90, Spruce 10 (Table 1);

\begin{tabular}{lll}
\hline Scale of ecological stability & Deviation from three-layer stand & Characteristics \\
\hline 1. very large & up to $10 \%$ & three layers of native species \\
2. high & $11-35 \%$ & two layers of native species \\
3. medium & $36-50 \%$ & two layers, $50 \%$ of native species \\
4. small & $51-75 \%$ & two layers, 25\% of native species \\
5. unsuitable & over 76\% & one layer of non-native species \\
\hline
\end{tabular}

According to Ott et al. (1995) a transition from regularly and individually structured montane forests to trees arranged in clusters or biogroups has a decisive importance in the lasting stability and maintenance of favourable conditions for the restoration of subalpine forests. Therefore the paper analyses the change of horizontal structure with the change of altitude in the form of cluster-forming individuals. Frequency of individual trees and clusters was recorded in the following interval groups - 1, 2, 3-5, 5-10, 10-15 tree individuals.

In order to detect the statistical dependence between the evaluated parameters and the altitude there was used a one-way analysis of variance. The software STATISTICA 7.0 was used to do the calculation. in transect $T_{\text {II }}$ compartment 2128 the representation is as follows: Beech 93, Maple 2.5, Spruce 2.5, Larch 2 (Tab. 2).

The representation of beech is mutually comparable in both transects, and basically did not change with altitude. The representation of spruce, which was not to be found in the original tree species composition, is higher only in the compartment 2252A at an altitude of $1370-1380 \mathrm{~m}$ a.s.l. at the top of the transect $T_{I}$ characterized by $T_{V P} P_{D}$.

The formula for calculating the approximation by Papánek (1967) shows the following values of approximation: in compartment $2252 \mathrm{~A} a\left(\mathrm{~T}_{\mathrm{I}}\right)=80.0 \%$, in compartment 2128 $a\left(\mathrm{~T}_{\mathrm{II}}\right)=82.5 \%$, which represents a high level of suitability of the current tree species with

Table 1: Frequency of tree individuals with diameter $d 1,3 \geq 5 \mathrm{~cm}$ and tree species representation in transect TI, compartment $2252 \mathrm{~A}$

\begin{tabular}{|c|c|c|c|c|c|c|c|c|c|c|}
\hline & \multicolumn{2}{|c|}{${\text { Transect } T_{I}}_{1}$} & \multicolumn{2}{|c|}{$\mathbf{T V P}_{\mathrm{A}}$} & \multicolumn{2}{|c|}{$\mathrm{TVP}_{\mathrm{B}}$} & \multicolumn{2}{|c|}{ TVP $_{\mathrm{C}}$} & \multicolumn{2}{|c|}{$\mathbf{T V P}_{\mathrm{D}}$} \\
\hline & pcs.ha ${ }^{-1}$ & $\%$ & pcs.ha-1 & $\%$ & pcs.ha-1 & $\%$ & pcs.ha ${ }^{-1}$ & $\%$ & pcs.ha ${ }^{-1}$ & $\%$ \\
\hline Beech & 620 & 89.60 & 456 & 98,30 & 624 & 100.00 & 864 & 94.70 & 536 & 69.80 \\
\hline Spruce & 72 & 10.40 & 8 & 1.70 & 0 & 0.00 & 48 & 5.30 & 232 & 30.20 \\
\hline$\Sigma$ & 692 & 100.0 & 464 & 100.0 & 624 & 100.0 & 912 & 100.0 & 768 & 100.0 \\
\hline
\end{tabular}

$$
a\left(T_{I}\right)=100 \cdot\left(1-\frac{40}{200}\right)=80 \%
$$


Table 2: Frequency of tree individuals with diameter $d_{1,3} \geq 5 \mathrm{~cm}$ and tree species representation in transect $T_{\text {II, }}$ compartment 2128.

\begin{tabular}{|c|c|c|c|c|c|c|c|c|c|c|}
\hline & \multicolumn{2}{|c|}{ Transect $_{\text {II }}$} & \multicolumn{2}{|c|}{ TVP $_{\mathrm{E}}$} & \multicolumn{2}{|c|}{ TVP $_{\mathrm{F}}$} & \multicolumn{2}{|c|}{$\operatorname{TVP}_{G}$} & \multicolumn{2}{|c|}{$\mathbf{T V P}_{\mathrm{H}}$} \\
\hline & pcs.ha ${ }^{-1}$ & $\%$ & pcs.ha ${ }^{-1}$ & $\%$ & pcs.ha ${ }^{-1}$ & $\%$ & pcs.ha ${ }^{-1}$ & $\%$ & pcs.ha-1 & $\%$ \\
\hline Beech & 300 & 93.20 & 224 & 93.40 & 256 & 94.10 & 320 & 95.20 & 400 & 90.90 \\
\hline Maple & 8 & 2.48 & 8 & 3.30 & 16 & 5.90 & 0 & 0.00 & 8 & 1.80 \\
\hline Spruce & 8 & 2.48 & 8 & 3.30 & 0 & 0.00 & 16 & 4.80 & 8 & 1.80 \\
\hline Larch & 6 & 1.86 & 0 & 0.00 & 0 & 0.00 & 0 & 0.00 & 24 & 5.50 \\
\hline$\Sigma$ & 322 & 100.0 & 240 & 100.0 & 272 & 100.0 & 336 & 100.0 & 440 & 100.0 \\
\hline
\end{tabular}

$a\left(T_{I I}\right)=100 \cdot\left(1-\frac{35}{200}\right)=82,5 \%$

respect to the original ones. Based on the calculated percentage of approximation we qualified both stands according to the classification scale (Vološčuk 2000) as very stable degree of ecological stability. The index of approximation (a) has a value 2 in both stands.

\section{Crown ratio $(c r)$}

Average values of crown ratio of all trees in transect $\mathrm{T}_{\mathrm{I}}$, compartment $2252 \mathrm{~A}$ reach $0.47 \pm 0.16$. Average crown ratio of beech was $0.49 \pm 0.15$. Spruce is located in the $4^{\text {th }}$ grade of relative height position of trees by Assmann (1961 in Saniga 2009). Their average crown ratio was $0.27 \pm 0.10$. Crown ratio of the trees in compartment 2252A decreases with increasing altitude (Fig. 1). In the lower half of the transect $\left(\mathrm{TVP}_{\mathrm{A}}-\mathrm{TVP}_{\mathrm{B}}\right)$ it decreased by $5.77 \%$ from $0.52 \pm 0.11$ at an altitude of $1340-1350 \mathrm{~m}$ a. s.l.to $0.49 \pm 0.16$ at an altitude of $1350-1360 \mathrm{~m}$ a. s. $\mathrm{l}$. In the upper half of the transect $\left(\mathrm{TVP}_{\mathrm{C}}-\mathrm{TVP}_{\mathrm{D}}\right)$ it decreased by $16.67 \%$ from $0.48 \pm 0.15$ at an altitude of $1360-1370 \mathrm{~m}$ a.s.l. to $0.40 \pm 0.18$ at an altitude of $1370-1380 \mathrm{~m}$ a.s.l.

Average crown ratio of all trees, in transect $\mathrm{T}_{\mathrm{II}}$, compartment $2252 \mathrm{~A}$, reached $0.57 \pm 0.13$. Average crown ratio value of beech was $0.57 \pm 0.13$. The highest values of average crown ratio are attributed to conifer species - spruce $0.70 \pm 0.07$, larch $0.63 \pm 0.12$. The lowest average crown ratio is attributed to maple $0.54 \pm 0.14$.

Analysis of variance in compartment 2252A statistically highly significantly $(p<0.0001)$ confirmed the relationship between crown ratio and altitude. This relationship did not appear in compartment 2128 to be statistically significant at the $95 \%$ of the significance level (p > 0.05) (Fig. 1).

Based on the average crown ratio of tree individuals we classified compartment 2252A in grade 4 (less stable), index $c r \mathrm{~T}_{\mathrm{I}}=4$, and compartment 2128 to grade 3 (moderately stable), index $\mathrm{cr} \mathrm{T}_{\text {II }}=3$ in the classification scale by Vološčuk (2000).
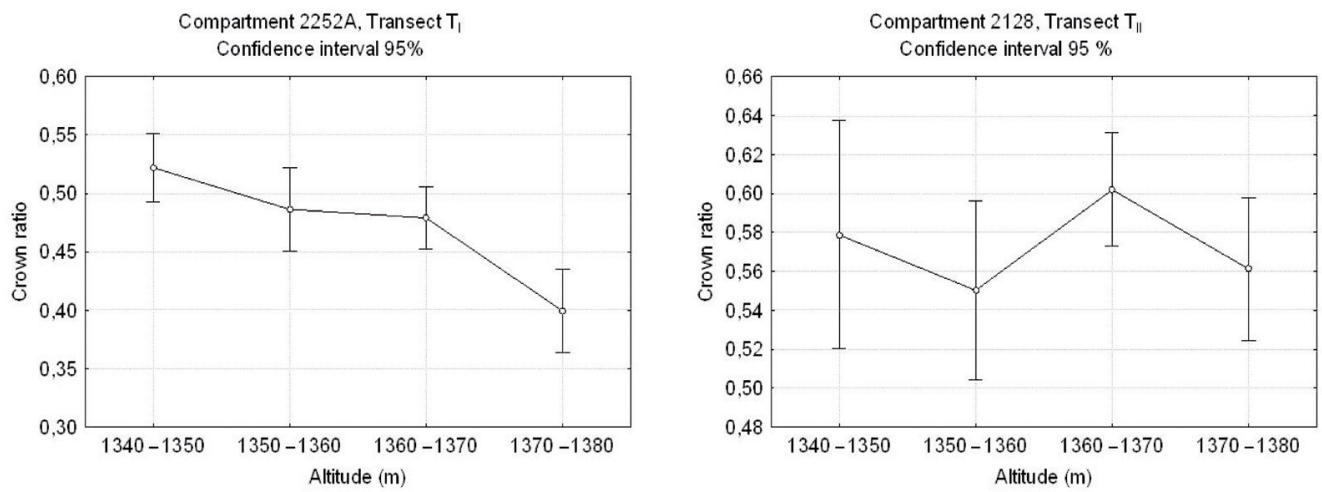

Fig. 1: Progress of crown ratio of tree individuals in transect $T_{I}$ and $T_{I I}$ depending on the altitude. 


\section{Slenderness quotient ( $s q$ )}

The sq in transect $T_{I}$ in the compartment $2252 \mathrm{~A}$ reached the value $0.60 \pm 0.17 \mathrm{~m} . \mathrm{cm}^{-1}$. It decreases with altitude and static stability of trees theoretically increases (Fig. 2). In the lower half of transect $\left(\mathrm{TVP}_{\mathrm{A}}-\mathrm{TVP}_{\mathrm{B}}\right)$ the value of $s q$ decreases by $7.25 \%$, from $0.69 \pm 0.17 \mathrm{~m} . \mathrm{cm}^{-1}$ at an altitude of $1340-1350 \mathrm{~m}$ a.s.l. to $0.64 \pm 0.14 \mathrm{~m} . \mathrm{cm}^{-1}$ at an altitude of $1350-1360 \mathrm{~m}$ a.s.l. In the upper half of transect $\left(\mathrm{TVP}_{\mathrm{C}}-\mathrm{TVP}_{\mathrm{D}}\right)$ it decreases by $5.26 \%$ of $0.57 \pm 0.15 \mathrm{~m} . \mathrm{cm}^{-1}$ at an altitude of 1360 $1370 \mathrm{~m}$ a.s.l. to $0.54 \pm 0.18 \mathrm{~m} . \mathrm{cm}^{-1}$ at an altitude of 1370-1380 $\mathrm{m}$ a.s.l. (Fig. 2).

The sq in transect $\mathrm{T}_{\text {II }}$ compartment 2128 reach the value $0.55 \pm 0.19 \mathrm{~m} . \mathrm{cm}^{-1}$. It increases with altitude, static stability of tree individuals theoretically decreases. Even in the upper part of transect characterized as $\mathrm{TVP}_{\mathrm{H}}$ it still falls into the grade of highly stable trees in the classification scheme by Míchal (1992).

The analysis of variance confirmed a statistically highly significant dependence of slenderness quotient on altitude in transect $T_{I}$ $(\mathrm{p}<0,0001)$ and $\mathrm{T}_{\mathrm{II}}(\mathrm{p}<0,001)$.

Based on the values of sq both stands were classified into the $2^{\text {nd }}$ grade of stability (very stable) of the classification scale by Vološčuk (2000). Index $s q \mathrm{~T}_{\mathrm{I}}=2$. Index $s q \mathrm{~T}_{\mathrm{II}}=2$.

\section{Sanitary coefficient (sc)}

Sanitary coefficient was calculated with respect to the most common damage to trees

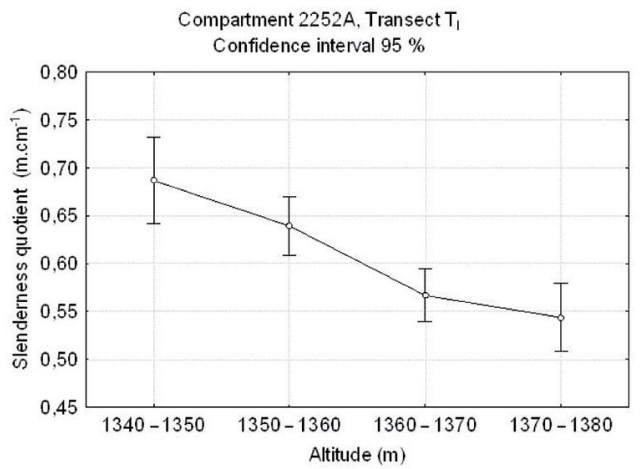

at the upper treeline ecotone in the form of necrotic damage to the bark.

When calculating ecological stability, as damaged were considered the tree individuals, where necrotisation became evident by wood denudation with a degree of necrotisation 3 and 4 in the classification scale Cicák, Mihál (2000). In the compartment 2252A there is $26,93 \%$ of the tree individuals with a specific degree of necrotisation, in the part 2128 there is approximately the same share of $25.16 \%$ (Table 3).

Based on the values of sanitary coefficient (25.16-26.93\%) were both compartments included in the second grade of ecological stability (percentage of damage 21-30\%) of the classification scale by Vološčuk (2000). Index sc $T_{I}$ $=2$. Index sc $\mathrm{T}_{\mathrm{II}}=2$.

\section{Coefficient of layering $(\boldsymbol{c l})$}

Transect $\mathrm{T}_{\mathrm{I}}$ in compartment $2252 \mathrm{~A}$ is multilayered with the representation of the upper layer of $47.7 \%$, middle layer of $38.2 \%$, and the bottom layer of $14.1 \%$ of the total number of tree individuals with diameter at breast height $d_{1,3} \geq 5 \mathrm{~cm}$. Since spruce is not to be found in the original, outlook representation, when classifying a stand into a grade of ecological stability by Vološčuk (2000) we characterize vertical construction as two layers of native species with $2^{\text {nd }}$ grade of ecological stability

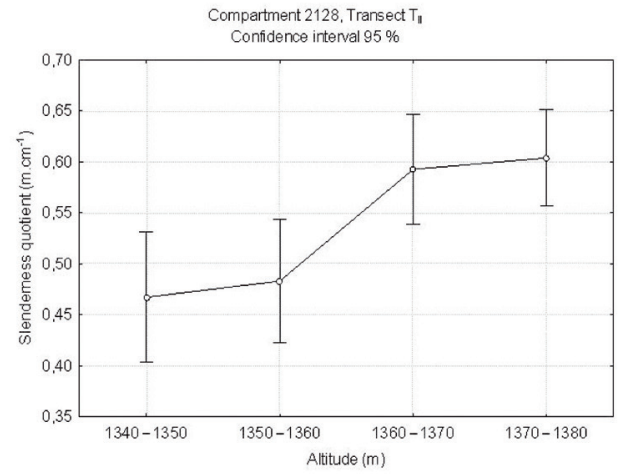

Fig. 2: Progress of slenderness quotient in transect $T_{I}$ and $T_{I I}$ depending on altitude.

Table 3: The proportion of trees et each stage of necrotisation in registered compartments.

\begin{tabular}{|c|c|c|c|c|c|c|}
\hline \multicolumn{6}{|c|}{ Stage of necrotisation/proportion of individuals (\%) } & \multirow{2}{*}{ Total \% } \\
\hline & 0 & 1 & 2 & 3 & 4 & \\
\hline 2252A & 26.44 & 32.21 & 14.42 & 16.35 & 10.58 & 100.00 \\
\hline 2128 & 36.77 & 25.81 & 12.26 & 10.32 & 14.84 & 100.00 \\
\hline
\end{tabular}




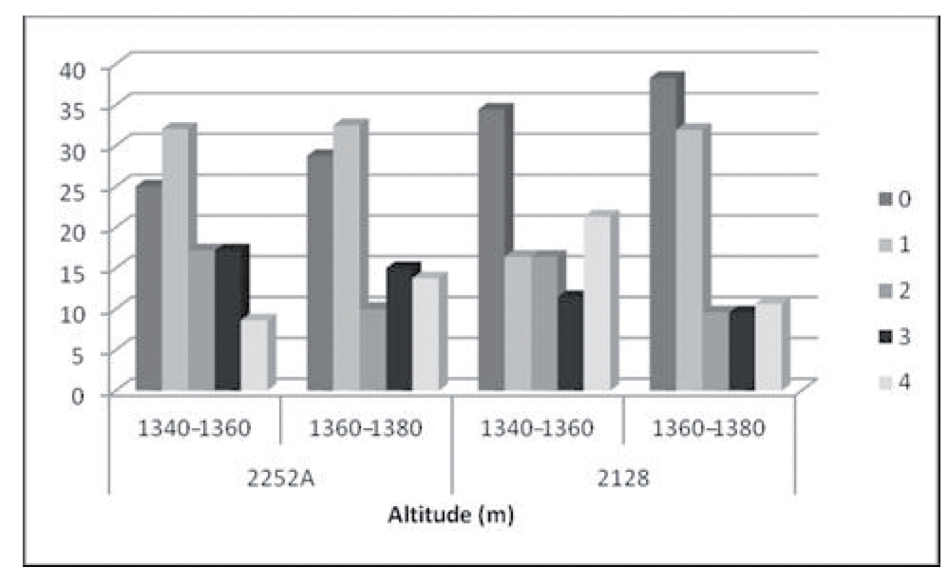

Fig. 3: The proportion of trees with a varying degree of necrotisation (0 - no necrotic wounds to 4-large necrotic wounds) in the lower and upper half of transects in the registered compartments.

and a deviation from a three-layered stand of $11-35 \%$. Index cl $\mathrm{T}_{\mathrm{I}}=2$.

Transect $\mathrm{T}_{\text {II }}$ compartment 2128 is twolayered with the representation of the top layer of $74.53 \%$ and the middle layer of $25,47 \%$ of the total number of tree individuals with diameter at breast height $d_{1,3} \geq 5 \mathrm{~cm}$. Based on two layers of native species we estimate the ecological stability of the compartment 2128 as high ( $2^{\text {nd }}$ grade), with a deviation from the three-layer stand of $11-35 \%$. Index $\mathrm{cl} \mathrm{T}_{\mathrm{II}}=2$. Vertical construction of the treeline is affected by clusters of beech (Fig. 4).
Fig. 4: The proportion of individuals in clusters, transect $\mathrm{T}_{\mathrm{I}}$ compartment $2252 \mathrm{~A}$ and transect $\mathrm{T}_{\text {II }}$ compartment 2128 .

\section{The resulting value of ecological stability}

Part 2252A: $E S T_{I}=5.2+3.2+4+2+2=24$

Part 2128: $E S T_{I I}=5.2+3.2+3+2+2=23$

Based on the resulting index of ecological stability $\left(\mathrm{EST}_{\mathrm{I}}=24, \mathrm{ES} \mathrm{T}_{\mathrm{II}}=23\right)$, the studied ecosystems at the treeline ecotone were classified in the second most stable grade of a 5-grade

Table 4: Biosociological position of trees in a classification scale by Assmann (1961 in Saniga 2009)(\%).

\begin{tabular}{ccccccc}
\hline & Dominant & Level & Semi-level & $\begin{array}{c}\text { Underlevel } \\
\text { shaded }\end{array}$ & Supressed & Total \\
\hline $\mathbf{2 2 5 2}$ & 6.00 & 18.00 & 34.85 & 26.29 & 14.86 & 100 \\
$\mathbf{2 1 2 8}$ & 21.12 & 27.33 & 24.22 & 21.74 & 5.59 & 100 \\
\hline
\end{tabular}

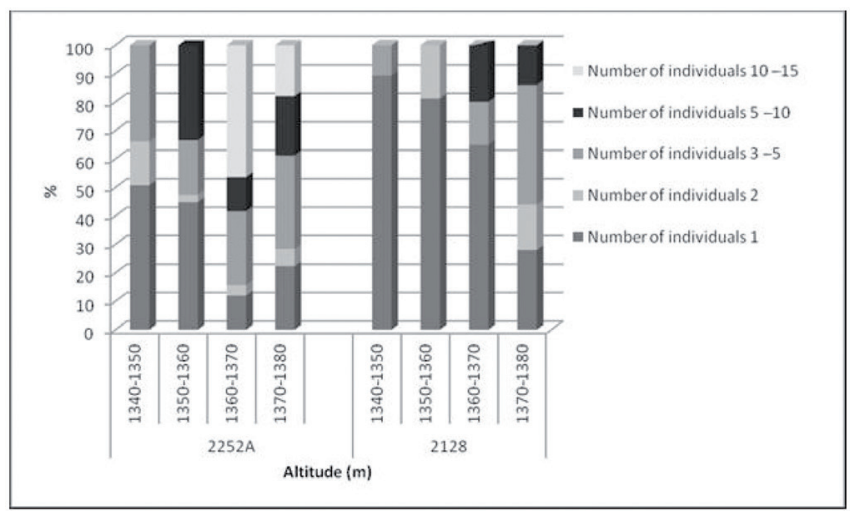

Fig. 4: The proportion of individuals in clusters, transect $T_{I}$ compartment $2252 \mathrm{~A}$ and transect $\mathrm{T}_{I I}$ compartment 2128. 
scale by Vološčuk (2000). We estimate the ecological stability in the registered transects $T_{I}$ and $\mathrm{T}_{\mathrm{II}}$ as "very good" (Index ES 16-24).

\section{Discussion}

The resulting index of ecological stability is composed of five indicators that change dynamically at extreme conditions of growth at the upper treeline ecotone.

Approximation of the current tree species composition with respect to the original ones reached high values $(80.0-82.5 \%)$ in the registered transects $\mathrm{T}_{\mathrm{I}}$ and $\mathrm{T}_{\mathrm{II}}$ at the upper treeline ecotone formed by beech. The ratio of tree species composition did not change significantly with the change of altitude. The basic tree species in all $\mathrm{TVP}_{\mathrm{A}-\mathrm{H}}$ was beech represented by $69.8-98.3 \%$ (Tab. 1, Tab. 2). Beech proportion in both parts was lowest in the upper part of transects $\left(\mathrm{TVP}_{\mathrm{D}}, \mathrm{TVP}_{\mathrm{H}}\right)$ at an altitude of 1370-1380m a.s.l. In compartment 2252A, there was an increased proportion of spruce (30.2\%) (Tab. 1) in TVP $_{D}$ which boarders with the alpine zone (ridges) at an altitude of $1370-1380 \mathrm{~m}$ a.s.l. Within compartment 2128 in the peripheral TVP $_{\mathrm{H}}$ of the transect $\mathrm{T}_{\mathrm{II}}$ at an altitude of 1370-1380 m a.s.l. there was increased proportion of spruce, larch and maple (Tab. 2). The southern exposure of the Low Tatras expanding from Hiadel'ská valley to Telgárt was originally formed by acidophilous beech forests (Luzulo-Fagion p.p.maj.) and calcareous beech forests (Cephalanthero-Fagenion). These were followed by spruce blueberry forests (Eu-Vaccinio-Piceenion p.p.) (Bystrický 2007). An increased representation of spruce in the upper part of the transects $\left(\mathrm{TVP}_{\mathrm{D}}, \mathrm{TVP}_{\mathrm{H}}\right)$ is therefore natural, even though spruce does not occur in the original representation in group of forests types Fageto-Aceretum humile. In the beech variation of the treeline in the Carpathians. Kricsfalusy et al. (2008) describes a tree species composition that comprises beech with admixture of sycamore (Acer pseudoplatanus) and rowan (Sorbus aucupariasubs. Glabrata), which corresponds to the species composition in our compartments. Rowan was not registered among the tree individuals with diameter $d_{1,3} \geq 5 \mathrm{~cm}$, however it is dominant among the individuals of natural regeneration (Gubka 1999, Mičovský 2013). Approximately the same tree species representation - beech $77 \%$, maple $17 \%$, spruce $6 \%$ is mentioned by Saniga et al. (2013) in group of forests types FAc hum in the beech primeval forest Skalná Alpa.
The average crown ratio value provides very useful information about existing silviculture management as well as resistance potential of stands (Šmelko 2000). Crown ratio of individual trees in the registered transects ranged from $0.47 \pm 0.16$ in the transect $T_{\mathrm{I}}$ to $0.57 \pm 0.13$ in the transect $T_{I I}$ (Fig.1). Crown ratio value declined with increasing altitude in compartment $2252 \mathrm{~A}$ from $0.52 \pm 0.11$ at an altitude of $1340-1350 \mathrm{~m}$ a.s.l. to $0.40 \pm 0.18$ at an altitude of 1370-1380 m a.s.l. (Fig. 1). Crown ratio in compartment 2128 was higher compared to the $2252 \mathrm{~A}$, it ranged from $0.55 \pm 0.13$ at an altitude of $1350-1360 \mathrm{~m}$ a.s.l. to $0.60 \pm 0.09$ at an altitude of 1360-1370 m a.s.l. (Fig. 1). In compartment 2128 the change in crown ratio with the change in altitude did not show to be statistically significant. Reduction of crown ratio with increasing altitude in part 2252A may be associated with density and increased canopy in the upper part of registered transects $\left(\mathrm{TVP}_{\mathrm{D}}, \mathrm{TVP}_{\mathrm{H}}\right)$. Increased canopy is specified by changing of horizontal structure, which is significantly shaped by clusters of trees (Fig. 4). Similar results have been confirmed in the analysis of the horizontal structure based on the aggregation index of Clark-Evans at the upper treeline ecotone formed by beech in the Dumbierske Tatras (Mičovský, Gubka 2012). Small crowns and a centre of gravity set high result in reduced static stability of the trees against the wind (Gubka 1999, Saniga 2011). This risk is naturally reduced in the upper treeline ecotone formed by beech by a formation of clusters of trees (Fig. 4). Although beech has the ability to significantly enlarge the volume of the crown having enough space, and after heavy interventions in a short time it can once again create a strong canopy (Šmelko et al. 1992), such interventions in the upper treeline ecotone would not be adequate in terms of stability as well as competitively strong herbal vegetation.

Slenderness quotient as the main indicator of static stability of stands is important in assessing the stands particularly with regard to mechanically acting factors causing damage (wind, snow, frost) (Vorčák et al. 2007). In the registered transects it ranged from $0.55 \pm 0.19 \mathrm{~m} \cdot \mathrm{cm}^{-1}\left(\mathrm{~T}_{\mathrm{II}}\right)$ to $0,60 \pm 0,17$ $\left(T_{T}\right)$ (Fig. 2). Trees with a slenderness quotient of less than 0.80 are considered very stable, and those of less than 0.55 are considered the trees with the highest stability (Míchal 1992). Analysis of variance confirmed a highly significant dependence $(p<0.001)$ between the slenderness quotient and altitude. Kucbel 
(2011) reports values of slenderness quotient in the alpine forest located on the western slopes of Prašivá in the Low Tatras in SobretoPiceetum in the range of $0.80-0.81$. This means that beech in the upper treeline ecotone compared to spruce exhibit comparable or better static stability.

When assessing the health status of the registered transects, damaged trees were considered those with fractured bark and exposed timber according to the methodology by Cicák, Mihál (2000). Despite the fact that at least small bark damage (grade of necrotisation 1,2 ) was recorded at $38.07-46.43 \%$ of individuals (Tab. 3), it is not necessary to consider this range of damage as damage interrupting the stability of the upper treeline ecotone. The proportion of trees without any necrotic bark disease (gr. 0) increased in the upper half of registered transects $\left(\mathrm{TVP}_{\mathrm{C}}, \mathrm{TVP}_{\mathrm{D}}\right.$ $\mathrm{TVP}_{\mathrm{G}}, \mathrm{TVP}_{\mathrm{H}}$ ) at an altitude of $1360-1380 \mathrm{~m}$ a. s. l. (Fig. 3). The proportion of tree individuals with a degree of necrotic disease 3 and 4 in the upper area of the transects $\left(\mathrm{TVP}_{\mathrm{D}}, \mathrm{TVP}_{\mathrm{H}}\right)$ in compartment $2252 \mathrm{~A}$ increased by $2.97 \%$, while in the compartment 2128 it decreased by $12.57 \%$ (Fig. 3). Therefore it is not possible to confirm the results by Vorčák et al. (2007) from NPR Babia Hora, where the increase of altitude significantly increased the average percentage of damaged trees.

Vertical structure of registered compartments was evaluated as two-layer. The compartment $2252 \mathrm{~A}$ could be evaluated as a threelayer one with non-native species of spruce in the lower layer. Mičovský, Gubka (2012) evaluated the vertical differentiation of the upper treeline ecotone using the Gini's coefficient. Its values indicate a higher vertical differentiation in the upper area of the ecotone. Presumably, the clusters of trees on the border with the alpine zone increase the static stability of individuals. Multi-trunk, widely branched forms resembling spruce biogroups in the upper forest boundaries indicate previous anthropic impacts in the areas (cattle grazing) (Svoboda, Pagan 1965). The reason of the cluster formation according to several authors (Šebeň, Kucbel 2003, Holtmeier 2009) is their growth in microhabitats-like suitable areas as well as the formation of a crown shell, which serves as a protection from adverse climatic factors. Trees in biogroups best benefit from light. Clusters of beech in the upper treeline ecotone may arise from vegetative restoration of the lower branches of juvenile trees.

\section{Conclusion}

With regard to climate changes in the future it is possible to expect a gradual increase of periods of moisture in forest soils and a reduction of the amount of available water. Combined with other negative harmful factors, namely the increase of the concentration of heterogeneous contaminants, particularly in the surface layers of soil, this assumes great danger especially for shallow-rooted spruce (Tužinský 1993), which constitutes the largest share of stands in the upper treeline.

Based on the methodology by Vološčuk (2000) this paper confirmed a very good ecological stability of the upper treeline ecotone, which in a part of the Dumbierské Low Tatras is formed by beech. In conjunction with the analysis of the regenerative capacity of treeline beech forests in the area (Mičovský 2013) it is possible to confirm a hypothesis that close to nature beech stands in the upper treeline ecotone maintain the natural ecological coupling even with the varying intensity of human intervention, they have considerable ecological stability and are capable of spontaneous natural recovery.

It is more than likely that the current development of climate will first destroy nonnative spruce forests in lower locations. Due to this there is an urgent need in forestry management and nature protection to respect and maintain the original ecotypes of species, though unproven, because the remnants of native vegetation are the best guarantee for natural regeneration, conservation of gene pool and ecological stability of forest ecosystems even under changed ecological conditions (Križová 2001).

\section{Literature}

Assmann, E. 1961: Waldertragskunde, München-Bonn-Wien, 490 s., In: Saniga, M., Pestovanie lesa, Vydavatel'stvo TU vo Zvolene, 2009, 311 p.

BieLY, A., BeŇuŠKa, P., BezÁK, V., BujnovsKÝ, A., Halouzka, R., IvaničKa, J., Kohút, M., Kuinec, A., Lukáčik, E., Maglay, J., Miko, O., Pulec, M., Putiš, M., VozÁr, J. 1992: Geologická mapa Nízkych Tatier 1 : 50000 [Geological map of the Low Tatras]. Bratislava, GÚDŠ.

BYstrickÝ, R. 2007: Využívanie lesov [Use of forests]. In: Národný park Nizke Tatry - prírodné hodnoty, história a súčasný stav ochrany územia, Správa NAPANT, Banská Bystrica, 116 p.

CicĀK, A., MiHÁl, I. 2000: Nekrotické ochorenie buka tracheomykózneho typu 
na Slovensku [Necrotic disease of beech tracheomycotic type in Slovakia]. Lesnická práce, 79 (7): 317-319.

FAšKo, P., ŠŤAstnÝ, P., 2002: Priemerné ročné úhrny zrážok $1: 2000000$ [The average annual rainfall], Atlas krajiny Slovenskej republiky, 1. vyd., Bratislava: Ministerstvo životného prostredia SR, Banská Bystrica: Slovenská agentúra životného prostredia, 344 p.

Fekete, L., Blattný, T. 1914: Die Verbreitung derforstlich wichtigen Bäume und Sträucher im ungarischen Staate. I. - II. Joerges. Schemnitz (Banská Štiavnica): Commissionsverlag von August Joerges' Witwe et Sohn, 147 p.

GuBKA, K. 1999: Štruktúra smrekového porastu pod hornou hranicou lesa $\mathrm{v}$ dielci 105 na LS Malužiná [The structure of spruce forests at the treeline ecotone in compartment 105, Forest district Malužiná], Acta Facultatis Forestalis Zvolen, 41: 107-119.

HANČINSKÝ, L. 1972: Lesné typy Slovenska [Forest types of Slovakia], Vydala Príroda, n. p., Bratislava, $307 \mathrm{p}$.

Holtmeier, F. K. 2009: Mountain Timberlines: Ecology, Patchiness, and Dynamics, Springer Science \& Business Media B.V., Berlin, 437 p.

Jasík, M., PolÁk, P. (eds.) 2011: Pralesy Sloven$s k a$ [Virgin forsts of Slovakia], FSC Slovensko, Banská Bystrica, 228 p.

KorpeL, Š. 1991: Pestovanie lesa [Silviculture], Príroda, Bratislava, $472 \mathrm{p}$.

Kricsfalusy, V., Mróz, W., Popov, S. 2008: Historical changes of the upper tree line in the Carpathian Mountains (Ukraine), http://www.mtnforum.org.

KRIŽOVÁ, E., 2001: Fytocenológia a lesnícka typológia [Phytocenology and forest typology], Zvolen, Vydavatel'stvo TU vo Zvolene, $182 \mathrm{p}$.

KuCBEL, S. 2011: Štruktúra porastov a regeneračné procesy vo vysokohorských ochranných lesoch Nizkych Tatier [Stand structure and regeneration processes in high altitude protected forests of Low Tatras]. Technická univerzita vo Zvolene, $138 \mathrm{p}$.

KuKLA, J. 2011: Buk ako edifikátor lesných geobiocenóz [Beech - edificator of forest geobiocenoses]. In: Buk a bukové ekosystémy Slovenska, Barna, M., Kulfan, J., Bublinec, E., (Eds.), Veda, Bratislava, 123-144.

Lapin, M., FašKo, P., Melo, M., SŤastný, P., Tomlain, J. 2002: Klimatické oblasti [Climatic zones] 1: 1000000, Atlas krajiny Slovenskej republiky, 1. vyd., Bratislava: Ministerstvo životného prostredia SR, Banská Bystrica: Slovenská agentúra životného prostredia, 344 p.

MičovsKÝ, J., GubKA, K. 2012: Štruktúra bukových porastov v ekotone hornej hranice lesa v Ďumbierskych Nízkych Tatrách [Structure of beech stands at the upper treeline ecotone in Ďumbier part of Law Tatras], In: Pestovanie lesa v strednej Európe, SANiga, M., KucBel, S., JALoviar, P., (eds.), Technická univerzita vo Zvolene, $356 \mathrm{p}$.

MıčovsKÝ, J. 2013: Regenerácia vrcholových bučín v Ďumbierskych Tatrách [Regeneration processes of alpine beech forests in Ďumbier Tatras]. In: Aktuálne problémy v zakladani a pestovanílesa, Bednárová, D. (eds.), Národné lesnícke centrum - Lesnícky výskumný ústav Zvolen, 95-103.

MidRIAK, R. 1973: Antropogénne vplyvy na vegetáciu a pôdu vo vysokých pohoriach západných Karpát [Anthropogenic impacts on vegetation and soil in the high ranges of the Western Carpathians]. Zborník lesnickeho, drevárskeho a polovníckeho múze 1973, 148-185.

Míchal, I. 1992: Obnova ekologické stability lesů [The restoration of ecological stability of forests], Academia Praha, 169 p.

Ott, E., Hladík, M., Korpel, Š., Saniga, M. 1995: Pestovanie horských lesov Švajciarska a Slovenska [Switzerland and Slovakia mountain forests silviculture], ÚVVP LVH SR, Zvolen, 127 p.

Pagan, J. 1999: Lesnícka dendrológia [Forest dendrology]. Technická univerzita vo Zvolene, 78 p.

PAPÁNeK, F. 1967: Doplňok k spôsobu určovania stupňa vhodnosti druhového zloženia porastov vzhl'adom na prevádzkové ciele. Rukopis. [Supplement to the method of determining the degree of suitability of species composition stands with regard to operational objectives. Manuscript], LVÚ Zvolen. In: VološčUK, I., 2000: Ekologická stabilita lesných ekosystémov, In: Ochrana prírody, Banská Bystrica, 18: 223-237.

Plesník, P. 1971: Horná hranica lesa vo Vysokých a Belianskych Tatrách [The tree-line in the High Tatras and Belianske Tatra], SAV Bratislava, $240 \mathrm{p}$.

SANiga, M. 2011: Bukové pralesy [Primeval beech forests]. In: Buk a bukové ekosystémy Slovenska, Barna, M., Kulfan, J., Bublinec, E., (Eds.), Veda, Bratislava, 209-226.

Saniga, M., Zrak, J., Pittner, J., Balanda, M. 2013: Štruktúra, produkcia, regeneračné procesy a disturbančný re⿻̌im prírodného lesa $v$ NPR Skalná Alpa [Structure, production, regeneration processes and distribution mode of natural forest in NNR Skalná Alpa]. Vydavatel'stvo Technickej univerzity vo Zvolene, 68 p.

Svoboda, P., Pagan, J. 1965: Lesnícka dendrológia II [Forest dendrology II], Slovenské vydavatel'stvo pôdohospodárskej literatúry, Bratislava, 392 p. 
ŠEBeŇ, V., Kucbel, S. 2003: Terminologické vymedzenie pojmu bioskupina ako základnej jednotky výstavby porastov v oblasti hornej hranice lesa [Terminological definition of the term biogroup as the basic unit of stand construction at the upper treeline ecotone]. Les, 2: 5-7.

ŠmelKo, Š., WenK, G., Vaidotas, A. 1992: Rast, štruktúra a produkcia lesa [Growth, structure and forest production]. Príroda, Bratislava, $342 \mathrm{p}$.

Šmelko, Š. 2000: Dendrometria [Dendrometry], Vysokoškolská učebnica, Vydavatel'stvo TU vo Zvolene, 399 p.

ŠŤastný, P., Nieplová, E., Melo, M. 2002: Priemerná ročná teplota vzduchu 1:2000 000 [Average annual air temperature]. Atlas krajiny Slovenskej republiky, 1. vyd., Bratislava: Ministerstvo životného prostredia SR, Banská Bystrica: Slovenská agentúra životného prostredia, $344 \mathrm{p}$.

Tomlain, J., Hrvol, J. 2002: Priemerná ročná teplota aktívneho povrchu pôdy $1: 2000000$ [Average annual temperature of the active surface of soil]. Atlas krajiny Slovenskej republiky, 1. vyd., Bratislava: Ministerstvo životného prostredia SR, Banská Bystrica: Slovenská agentúra životného prostredia, 344 p.

TuŽINSKÝ, L. 1993: Vplyv klimatických zmien na vlhkost pôdy v lesných ekosystémoch [The impact of climate change on soil moisture in forest ecosystems], Agrometeorologická konference 93, Sborník referátu. ČBkS, Brno, 44-48.

Vološčuk, I. 2000: Ekologická stabilita lesných ekosystémov [The ecological stability of forest ecosystems], In: Ochrana prírody, Banská Bystrica, 18: 223-237.

Vorčák, J., Merganič, J., Merganičová, K. 2007: Ekologická stabilita lesných porastov v NPR Babia Hora [The ecological stability of forest stands in National nature reserve Babia Hora], Beskydy, 20: 275-282.

Zdycha, P., Korimová, G., Urgela, J. 1992: Dejiny lesnictva [The History of Forestry]. Technická univerzita vo Zvolene, 172 p. 
